\title{
Estimation of Water Loss Due to Evaporation in the El Cazadero Dam, Mexico, during a Drought*
}

\author{
Pedro Antonio Guido Aldana - Yves Alexis Pardavell Juárez ${ }^{b}$. Pino Durán \\ Escamillac
}

\begin{abstract}
In Mexico, large dams have been a critical component of the water supply. However, the places where they can be built are scarcer every day, a situation that adds to the high costs and social conflicts that they cause. Much of the water stored in dams is lost due to evaporation, so technological alternatives are currently being investigated to reduce it. Regarding the determination of evaporated volumes, data obtained with evaporimeters do not represent actual evaporation, being necessary to apply theoretical models in combination with field measurements to reach better approximations. The main objective of this research is to calculate the water evaporation in the El Cazadero dam located in the State of Zacatecas, Mexico, through Penman's semi-empirical equation using data from the El Cazadero or 32006 weather station. The study area was selected due to its aridity and recurring drought problems that affect water availability. Evaporation results obtained from applying the theoretical model are compared with those reported by the weather station, showing a good correlation. In addition, results of the average daily evaporation are used to determine the approximate volume of water evaporated in the hydrological year between November 2010 and October 2011, when a severe drought occurred, whose magnitude and economic value indicates the necessity to carry out more research on this subject and propose public policies to develop and implement technological alternatives that mitigate this phenomenon.
\end{abstract}

Keywords: Evaporation; Penman's equation; precipitation; dams; droughts; climate change; public policies

Received: 28/10/2020 Accepted: 08/03/2021 Available online: 23/07/2021

* Research article

a PhD in Engineering and MSc in Hydraulic Engineering, Universidad Nacional Autónoma de México (UNAM). BSc in Civil Engineering. Researcher, Instituto Mexicano de Tecnología del Agua (IMTA), Mexico. Member of the Coordinación de Desarrollo Profesional e Institucional. Instituto Mexicano de Tecnología del Agua, Jiutepec, México. E-mail: guido.pedro@gmail.com ORCID: https://orcid.org/0000-0002-9711-4228

b MSc in Civil Engineering. Escuela Superior de Ingeniería y Arquitectura. Instituto Politécnico Nacional. Mexico City, Mexico. E-mail: yves.pardavell@hotmail.com

c Professor/Researcher. Escuela Superior de Ingeniería y Arquitectura. Instituto Politécnico Nacional. Mexico City, Mexico. E-mail: pduran@ipn.mx 
How to cite: P. A. Guido Aldana, Y. A. Pardavell Juárez, and P. Durán Escamilla, "Estimation of Water Loss Due to Evaporation in the El Cazadero Dam, Mexico, during a Drought", Cien.Ing.Neogranadina, vol. 31, no. 1, pp. 73-91, Jul. 2021.

\section{Estimación de la pérdida de agua por evaporación en la presa El Cazadero, México, durante una sequía}

Resumen: en México, las grandes represas han sido un componente crítico del suministro de agua. Sin embargo, los lugares donde se pueden construir son cada día más escasos, una situación que se suma a los altos costos y conflictos sociales que causan. Gran parte del agua almacenada en las presas se pierde debido a la evaporación, por lo que actualmente se están investigando alternativas tecnológicas para reducirla. En cuanto a la determinación de volúmenes evaporados, los datos obtenidos con evaporómetros no representan la evaporación real, siendo necesario aplicar modelos teóricos junto con mediciones en campo para lograr mejores aproximaciones. El objetivo principal de esta investigación es calcular la evaporación del agua en la presa El Cazadero, ubicada en el Estado de Zacatecas, México, a través de la ecuación semiempírica de Penman, utilizando datos de la estación meteorológica El Cazadero o 32006. El área de estudio fue seleccionada debido a su aridez y problemas recurrentes de sequía que afectan la disponibilidad de agua. Los resultados de evaporación obtenidos de la aplicación del modelo teórico se comparan con los reportados por la estación meteorológica, mostrando una buena correlación. Además, los resultados de la evaporación media diaria se utilizan para determinar el volumen aproximado de agua evaporada en el año hidrológico entre noviembre de 2010 y octubre de 2011, cuando se produjo una grave sequía, cuya magnitud y valor económico indica la necesidad de realizar más investigaciones sobre este tema y proponer políticas públicas para desarrollar e implementar alternativas tecnológicas que mitiguen este fenómeno.

Palabras clave: evaporación, ecuación de Penman, precipitación, presas, sequías, cambio climático, políticas públicas. 


\section{Introduction}

Water constitutes the central theme of sustainable development. It is crucial for the countries' socio-economic progress, energy generation, food production, and ecosystem conservation. The water demand is expected to increase in a warmer climate, creating greater competition for this good between different sectors, mainly agriculture, urban and industry (including tourism), and energy. Consequently, new policies, strategies, and technologies are required to help guarantee water security.

Water loss through evaporation in reservoirs is a problem that can be of considerable economic importance, particularly in arid areas with minimal rainfall, and a challenge for water resource management. Due to this phenomenon, the losses can reach, under certain conditions of extreme solar radiation, up to $75 \%$ of the precipitated water [1].

Mexico has a large part of its territory in the high-pressure northern zone, and therefore, two-thirds are considered arid or semi-arid, with annual rainfall less than $500 \mathrm{~mm}$ [2]. These areas are more susceptible to droughts because of the low rainfall throughout the year (one month for arid areas and one to three months for semi-arid areas). This condition causes droughts to occur more frequently and more significant pressure on the available water [3], in addition to the high rates of evaporation because of solar radiation. Other factors such as orography, oceans, vegetation cover, and land use for human activities also influence climate. The Mexican states most vulnerable to drought are those in the north: Chihuahua, Coahuila, Durango, Nuevo León, Baja California, Sinaloa, Zacatecas, San Luis Potosí, Aguascalientes, Guanajuato, Querétaro, Hidalgo, and Tlaxcala [4]. Drought is a natural and recurring climatic phenomenon that occurs virtually in all climatic regimes [5] but more frequently in arid and semi-arid areas [6]. The American Meteorological Society defines drought as "a period of abnormally dry weather whose duration is long enough to cause significant hydrological imbalances" [7].

In Mexico, the most severe drought in the century and recognized as the worst in 70 years occurred between 2010 and 2011. The number of people affected by this disaster amounted to 2.5 million [8]. In May 2011, the second driest since $1941,86 \%$ of the country experienced some degree of drought. As a result, drought emergency declarations were approved in 1,174 municipalities in the country [9]. The material impacts included a $29 \%$ loss of the national bean production in 2.7 million damaged agricultural hectares in Sinaloa, Zacatecas, and Guanajuato. In addition, 12 million heads of cattle showed loss of weight and production quality, resulting in the death of 0.45 million of them [10].

At present, population growth and economic activities exert tremendous pressure on water resources [2], [11]-[14]; therefore, the country requires a new management orientation not only to increase water availability but also to reduce its losses. In this context, we can affirm that the water loss due to the evaporation process has not been raised as a significant problem. However, today, with the growing demand, the decrease in its availability in some regions, and the challenges posed by climate change and its unpredictable consequences, the reduction of evaporation in dams and reservoirs becomes relevant.

Globally, investments in the design and implementation of water-saving measures are becoming a common practice in managing water resources. The entities responsible for its management seek to optimize water supply systems, including the reduction of evaporation losses in reservoirs. For this purpose, various methods have been developed, including synthetic material covers and floating solar panels that provide shade and take advantage of sunlight for power generation [15]-[22]. Other recent studies offer the possibility of converting the energy from evaporation into work. However, there is not much knowledge of the potential of natural evaporation as a renewable energy source, specifically energy availability, intermittency, and the impact on water resources [23].

Studies on climate change conclude that global warming will cause systematic changes in the components of the hydrological cycle and hydrological systems, such as alterations in precipitation patterns, intensity, and extremes; widespread 
melting of snow and ice; increment of atmospheric water vapor; changes in soil moisture and runoff; and particularly an increase in evaporation that will affect the availability of water [24]-[26]. Within this context, the estimation of evaporation in reservoirs is fundamental to propose new public policies related to water resource management; the design, operation, and sustainable use of these hydraulic works crucial for the sustainability of the Mexican water sector, and the design of technologies to mitigate evaporation in reservoirs, according to Mexico's situation and needs.

The following section presents some background information on the subject. Subsequently, we introduce the methodology to calculate the average daily evaporation in the El Cazadero dam for the hydrological year between November 1, 2010, and October 31, 2011; the determination of the variables involved in Penman's equation; the data used and their respective source; the results obtained and its analysis. Finally, we provide some conclusions and recommendations.

\section{Background}

Evaporation is a physical process that occurs when water, in a liquid state, turns into water vapor and is transferred to the atmosphere [27]. It cannot be measured directly in reservoirs and lakes, like precipitation or runoff from a riverbed, but it is necessary to estimate it through the various methods proposed in the literature, considering the available data. Collado [28] specifies that evaporation constitutes an essential component of the hydrological cycle, representing up to $60 \%$ of the precipitation on permeable lands. In addition, the evaporation data obtained with evaporimeters is potential but not actual evaporation, being necessary to have a physical model that describes the phenomenon and its relationship with temperature, atmospheric humidity, wind, among other variables, to calculate it [29].

For their part, Brutsaert and Parlange also state that measurements in evaporation trays do not represent actual evaporation [30]. Bates comments that the trends may be due to the decrease in solar radiation on the surface (for example, in the UsA and regions of Europe and Russia) and the shorter duration of sunlight (for example, in China, which may be related to increased air pollution, aerosol use, and more clouds) [31]. Collado [28] considers that it is essential to develop more research on the following topics: measurement of evaporation and its spatial distribution, the capture of evaporated water, the evaporation of salt water, among others, using remote sensing, condensation meshes, and solar energy, respectively.

Reservoirs whose purpose is to supply water to different sectors (urban, agricultural, industrial) require a periodic estimation of evaporation [32]. A limitation that may arise when performing calculations is a lack of data from a weather station, which is the main factor for uncertainty in the results. Calculations generally need the magnitude of meteorological variables such as wind velocity and humidity, which must be measured or estimated at the dam or reservoir.

Some proposals for calculating evaporation suggest using large-scale evaporation models (regional or basin) to obtain more reliable results. However, these types of models turn out to be complex because of their dependence on numerous meteorological variables, which has given rise to more simplified proposals with a smaller number of variables [33]-[35], without overcoming the classic Penman's equation [36]-[37].

Considering the complexity of the phenomenon of evaporation, it is possible to find numerous proposals in the literature more or less rigorous estimations. Sánchez and Corvacho specify that the diverse methods can be classified as follows: empirical, combination equation-based, and physicalbased [38]. The empirical methods are divided into two general groups: those based on air temperature, solar radiation, and temperature and those based on the combination equation of the energy balance and turbulent transfer of water vapor, also called semi-empirical [39]. The formulas of the first group are beneficial when other meteorological data are not available, but their results are less reliable [40] than those obtained with the methods of the other groups, although they improve after making local adjustments. 
The methods based on the combination equation, having a more robust theoretical base introduced into the model through empirical coefficients, can be applied anywhere in the world and allow for better results; however, they are highly demanding on input data.

Physical-based methods include Penman's formulation (1948) [36], those proposed later building on it, and, currently, that of Penman-Monteith, recommended by the Food and Agriculture Organization (FAO) for studies around the world [41]. The Penman-Monteith equation generates a time series of the evaporation rate of a body of water based on the water surface temperature, air temperature, wind velocity, and vapor pressure. Some research has proposed to know the degree of variation of the results after applying the different equations to support decision-making [42]-[43].

Techniques that involve remote sensors are used for data acquisition today to face the limitations of the methods [44]-[47], although their application is not widespread yet. While considered the least precise [48]-[49], the evaporation tray is the only method that does not require specific measurements in the place where the reservoir is located and, therefore, is usually employed in water resource research.

The interest in new proposals to calculate evaporation can be verified in the literature. Molina et al. [50] developed a model to estimate the evolution of water temperature and evaporation in irrigation regulation reservoirs. The model is based on energy balance on the reservoir's surface, considering the hypothesis of isothermal behavior. For its implementation, it is necessary to know the geometry of the reservoir (surface and depth) and the daily climatic data usually available at meteorological stations (solar radiation, wind velocity, relative humidity, and air temperature). In Australia, Yao et al. (2010) conducted a study based on the calculation of evaporation rates in open surface water bodies using the Penman-Monteith equation [51]-[52]. In this case, the Penman-Monteith approach considers changes in the amount of energy available for evaporation as a function of changes in the amount of heat stored within the body of water.

\section{Methods and Calculations}

\section{Penman's method}

Penman [36] developed a combination between the energy balance and the mass transfer method to obtain an equation that would calculate evaporation in a free water surface, based on the record of some climatological variables (hours of sunlight, temperature, humidity, and wind velocity). This method is also known as the combination method and was the first physically based expression to calculate potential evapotranspiration. Equation 1 was used to carry out the evaporation calculation in the El Cazadero dam.

$$
E=\frac{\frac{\Delta}{\gamma} R_{n}^{\prime}+E a}{\frac{\Delta}{\gamma}+1}
$$

Where E: daily evaporation in $\mathrm{mm}$; $\Delta$ : the slope of the saturation vapor pressure curve for air temperature in $\mathrm{mm} \mathrm{hg}{ }^{\circ} \mathrm{C}^{-1} ; \gamma$ : the psychrometric constant in $\mathrm{mm} \mathrm{hg}^{\circ} \mathrm{C}^{-1} ; \mathrm{R}_{\mathrm{n}}^{\prime}$ : net radiation in $\mathrm{mm}$ day ${ }^{-1}$; Ea: evaporation $\left(\mathrm{mm} \mathrm{day}^{1}\right)$, calculated as a function of vapor pressure and wind velocity.

\section{Hydrological data}

The El Cazadero dam belongs to the Río Grande or Aguanaval basin, which is of an interior or endorheic type with an area of $5,167 \mathrm{~km}^{2}$. Between 1941 to 1967, it exhibited a maximum runoff of 244 million $\mathrm{m}^{3}$ and a minimum of 19 million $\mathrm{m}^{3}$, having an annual average of 67 million $\mathrm{m}^{3}$. The maximum flood recorded was $437 \mathrm{~m}^{3} \mathrm{~s}^{-1}$ in August 1959. The Ordinary High Water Level (OHWL) capacity is 22.18 million $\mathrm{m}^{3}$, whose elevation is 1916 meters above sea level, covering an area of 457.73 ha. For the Extraordinary High Water Level (EHWL), it has a capacity of 44.68 million $\mathrm{m}^{3}$, at an elevation of 1919.94 meters above sea level, covering an area of 682.44 ha [53]. Fig. 1 provides the location of the El Cazadero dam in the State of Zacatecas. 


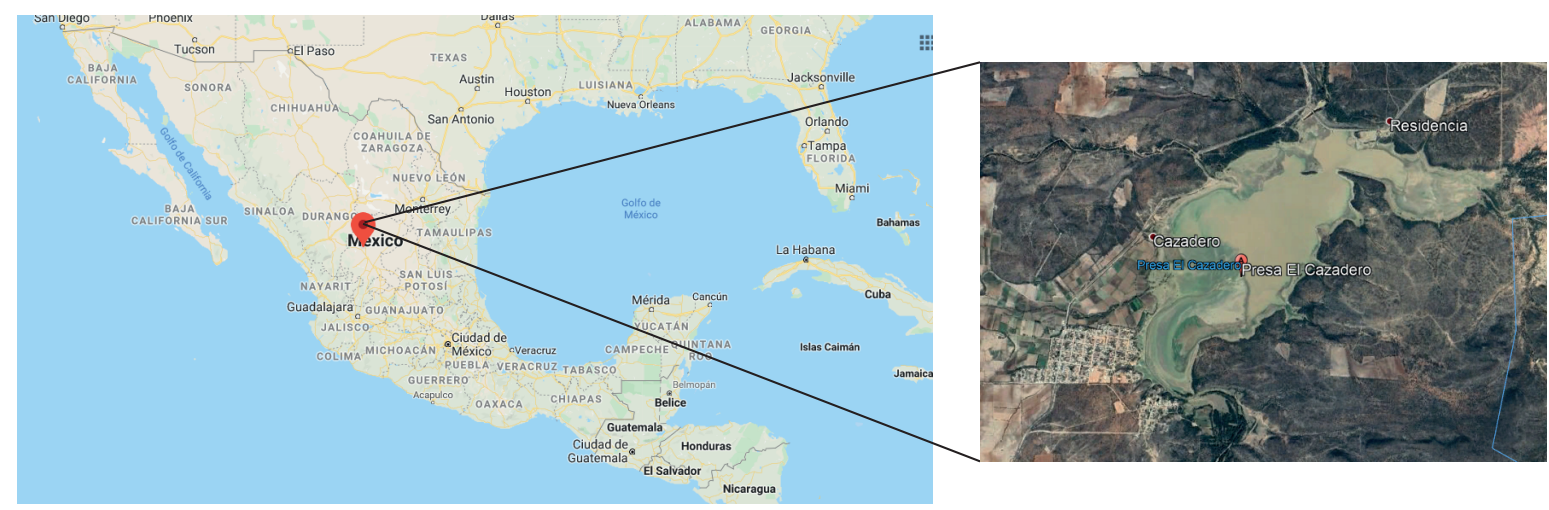

Fig. 1. Location of the El Cazadero dam, Municipality of Saín Alto, Zacatecas. Geographical coordinates: latitude: 23.6667; longitude: -103.1.

Source: Google Maps and Google Earth.

\section{Weather data}

It was necessary to collect climatological data for a hydrological year to perform the calculations, which in this case study is the one between November 2010 and October 2011, when a severe drought occurred in Zacatecas. Data from weather station number 32006 or El Cazadero (Table 1), operated by the National Water Commission (Conagua, for its acronym in Spanish) and the National Meteorological Service (sMn, for its acronym in Spanish), were used, being the former the one that provided the information.

Table 1. Data from the El Cazadero station by December 2015

\begin{tabular}{cc} 
Station & $\mathbf{3 2 0 0 6}$ \\
\hline Name & El Cazadero \\
\hline State & Zacatecas \\
\hline Municipality & Saín Alto \\
\hline Status & Operating \\
\hline Agency & Conagua-DGE \\
\hline Latitude & 23.6931 \\
\hline Longitude & -103.0936 \\
\hline Elevation & 1,862 masl \\
\hline
\end{tabular}

Source: Own elaboration

\section{Average daily temperature}

The mean daily temperature of the site was calculated in Celsius degrees from November 1, 2010, to October 31, 2011, using maximum and minimum values (2):

$$
T_{\text {med }}=\frac{T_{\max }+T_{\min }}{2}
$$

\section{Net solar radiation $(\mathrm{Rn})$}

The net radiation received by an albedo surface " $r$ " (the percentage of radiation that any surface reflects) is the portion of incident global radiation that is neither reflected nor re-irradiated to the atmosphere [1]. Equation 3 was used to estimate $\mathrm{Rn}$ in the $\mathrm{El} \mathrm{Ca-}$ zadero dam.

$$
R n=R i(1-r)-R l
$$

Where r: albedo, with values of 0.02-0.06 if the temperature is less than $30^{\circ} \mathrm{C}$ and $0.06-0.40$, when it is greater than $31{ }^{\circ} \mathrm{C}$; Ri: mean daily incident solar radiation in Langley/day ${ }^{-1}$; Rl: net longwave radiation in Langley/day ${ }^{-1}$.

\section{Solar radiation $(\mathrm{Ra})$ and incident solar radiation $(\mathrm{Ri})$}

Solar radiation reaches the outer limit of the atmosphere and is almost constant across the planet and all seasons of the year. It is also known as "Solar Constant"; this radiation can vary from 1.89 to 


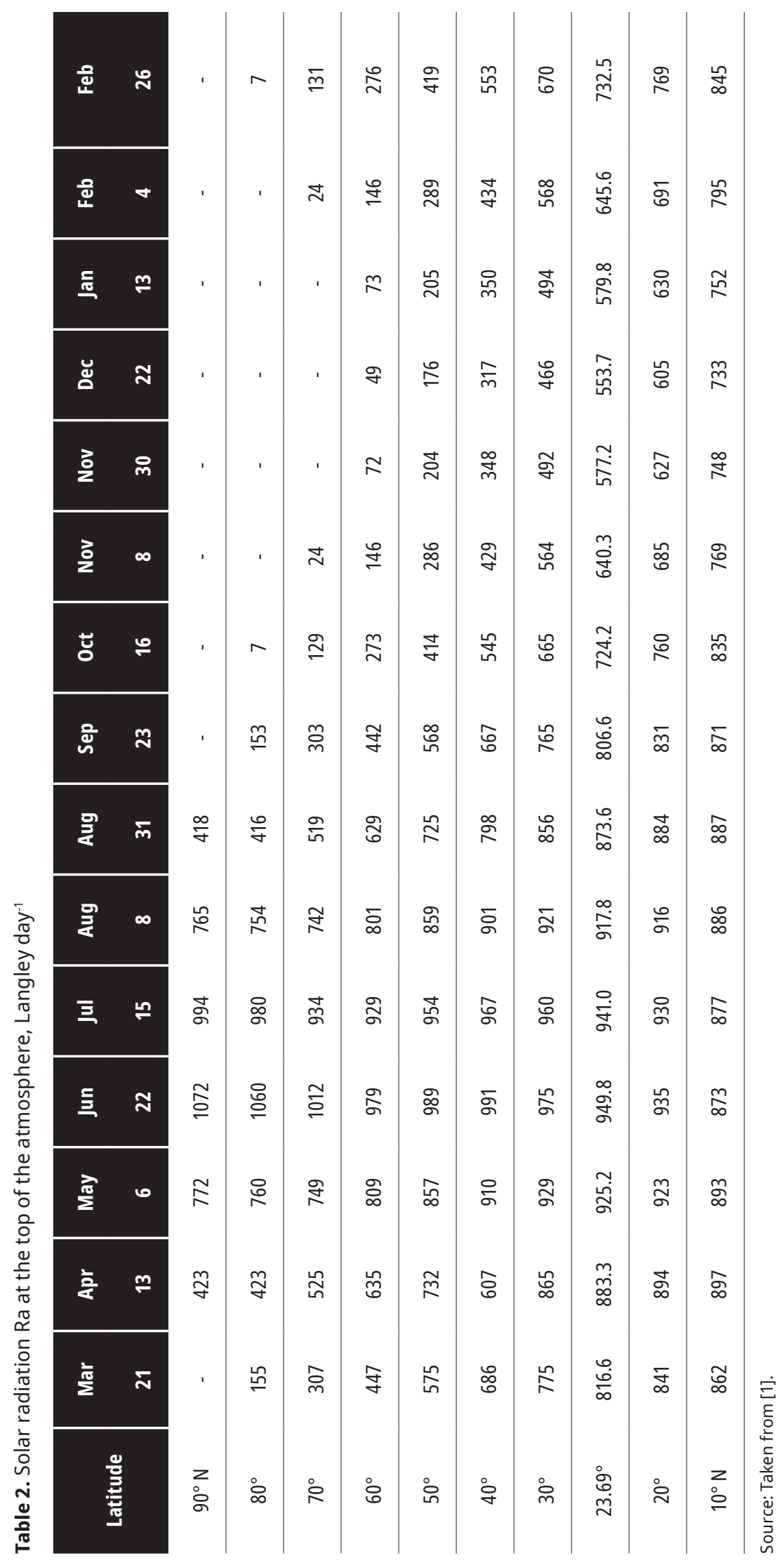


2.05 Langley $\mathrm{min}^{-1}$. It also depends on the absorption of the atmosphere and the amount of cloud cover [1]. For this study, a mean annual balance was used for the northern hemisphere, where the case study is located, as shown in Table 2.

We considered Latitude $23.69^{\circ}$ considered to obtain $\mathrm{Ra}$, in which the weather station El Cazadero or number 32006 is located. The data used in the evaporation calculations were obtained using a linear interpolation between latitude $20^{\circ}$ and $30^{\circ}$.

$\mathrm{Ra}$ is given in Langley (Ly), a unit used to measure solar radiation or insolation that reaches the upper part of the Earth's atmosphere or its surface in one day or one month. This study uses the units in the International System (sI) and the equivalence of (4).

$$
1 L y=1 \frac{\mathrm{Cal}}{\mathrm{cm}^{2}}
$$

With Equation 4, we converted all radiation and insolation measurements used in this research. For evaluating short-wave or incident radiation, two approaches were implemented: 1) From measurements with a pyrheliometer, and 2) indirect evaluation using observable and measurable parameters. This research took the second option, with an indirect estimation method proposed by A. Angström [54], which considers solar radiation (Ra), empirical constants, and insolation, as shown in (5) [1].

$$
R i=R a\left(a+b \frac{n}{N}\right)
$$

Where Ri: mean daily incident solar radiation (Langleys day ${ }^{-1}$ ); Ra: global incident radiation (Table 2, solar radiation); a, b: empirical constants; $\mathrm{n}$ : the observed duration of daylight hours per day (insolation); $\mathrm{N}$ : the maximum daily number of daylight hours as a function of the latitude of the place.

\section{Empirical constants "a" and "b"}

For his part, [55] used a modified version of the Angström's equation (Table 3), applying a correction for latitude. With this equation, we calculated the global irradiation in 32 stations in Mexico equipped with Campbell-Stokes-type insolation hour recorders and drew maps of isohels by freehand interpolation of global irradiation in January and July [56].

Table 3. Values of the constants "a" and "b" in the Angström's equation

\begin{tabular}{l|c|c|l}
\hline Location & A & B & Author(s) \\
\hline Worldwide & 0.23 & 0.48 & I. N. Black et al. (1934) \\
\hline Worldwide & $0.29 \cos \theta^{*}$ & 0.52 & $\begin{array}{l}\text { J. Glover and J. S. G. Mc } \\
\text { Culloch (1958) }\end{array}$ \\
\hline Virginia, USA & 0.22 & $0.54 \begin{array}{l}\text { Quoted by H. L. Penman } \\
(1948)\end{array}$ \\
\hline
\end{tabular}

Note. $\theta *$ : Longitude instead of degrees

Source: Taken from [1].

\section{Insolation $(\mathrm{n} / \mathrm{N})$}

In meteorology, insolation is the number of hours during which a surface receives sunlight $(\mathrm{N})$ in a given period (Table 4). In this research, evaporation was only estimated during sunlight hours, omitting nighttime hours. We considered sunrise to sunset to obtain the observed duration of daylight hours (n).

Table 4. Maximum daily average duration of sunlight hours (N)

\begin{tabular}{l|c|c|c|c|c}
\hline Latitude (N) & Jan & Feb & Mar & Apr & May \\
\hline $0^{\circ}$ & 12.1 & 12.1 & 12.1 & 12.1 & 12.1 \\
\hline $5^{\circ}$ & 11.9 & 12.0 & 12.1 & 12.2 & 12.4 \\
\hline $10^{\circ}$ & 11.6 & 11.8 & 12.1 & 12.3 & 12.7 \\
\hline $15^{\circ}$ & 11.4 & 11.6 & 12.1 & 12.4 & 13.0 \\
\hline $20^{\circ}$ & 11.1 & 11.4 & 12.0 & 12.6 & 13.3 \\
\hline $25^{\circ}$ & 10.8 & 11.3 & 12.0 & 12.8 & 13.7 \\
\hline
\end{tabular}

Source: Taken from [1].

\section{Net long-wave radiation ( $\mathrm{Rl}$ )}

The free surface of the water, the surface of the ground, or even the surface of the human body emits radiation since a property of solar radiation is that when it encounters a body, it is absorbed by that body, increasing its temperature, and emitting radiation at another wavelength. It can be stated 
that this body emits longwave radiation into the atmosphere, whose intensity depends essentially on its temperature, in this case, the free surface of the water [1]. The net longwave radiation ( $\mathrm{Rl})$ is calculated using Brunt's equation (6) [1].

$R l=\sigma T^{4}\left(0.56-0.914 \sqrt{e_{2}}\right)\left(0.10+0.9 \frac{n}{N}\right)$

Where Rl: net longwave radiation $\left(\mathrm{cal} \mathrm{m}^{-2} \mathrm{day}^{-1}\right)$; $\sigma$ : Stefan-Boltzmann constant, equal to $1171 \times 10^{-7}$ (cal cm ${ }^{-20} \mathrm{~K}^{-1} \mathrm{day}^{-1}$ ); T: temperature in ${ }^{\circ} \mathrm{K}$; $\mathrm{e}_{2}$ : vapor pressure of the air in $\mathrm{mm} \mathrm{hg.} \mathrm{We} \mathrm{calculated} \mathrm{Rl}$ based on the mean air temperature.

\section{Psychrometric constant $(\gamma)$}

The psychrometric constant $\gamma$ relates the partial pressure of water in the air with air temperature so that the vapor pressure can be estimated using the temperature readings from a wet or dry bulb thermometer. Another way to describe the psychrometric constant is through the relationship between the specific heat of moist air at constant pressure $(\mathrm{Cp})$ and the latent heat of vaporization [57].

Specific heat at constant pressure $(\mathrm{Cp})$ is the amount of energy required to increase the temperature of a unit mass of air by one degree at constant pressure. Its value depends on air composition, particularly its humidity. For the given atmospheric conditions, the mean value of $\mathrm{Cp}$ is $1.013 \times 10^{-3} \mathrm{MJ} \mathrm{kg}^{-10} \mathrm{C}$ (MJ: mega Joules). As the atmospheric pressure $(\mathrm{P})$ is a value of local character-that is, it depends on the place-it is possible to use the value obtained in situ. We maintained the psychrometric constant maintained for each location, although it is a function of the altitude, and calculated it using (7).

$$
\gamma=\frac{C p P}{\varepsilon \lambda}
$$

Where $\gamma$ : psychrometric constant in $\mathrm{KPa}{ }^{\circ} \mathrm{C}^{-1}$ (KPa: kilo Pascals); Cp: specific heat at constant pressure $\left(1.013 \times 10^{-3} \mathrm{MJ} \mathrm{kg}^{-10} \mathrm{C}\right)$; $\mathrm{P}$ : atmospheric pressure in $\mathrm{KPa}$; $\varepsilon$ : the molecular weight of the water vapor to dry air ratio (0.622); $\lambda$ : the latent heat of vaporization in $\mathrm{MJ} \mathrm{kg}^{-1}$.

\section{Slope of the saturation vapor pressure curve $(\Delta)$}

If the evaporation process occurs in a closed container, a time will come when there are as many molecules returning to the liquid state those escaping to the gaseous state. At this point, the vapor is said to be saturated, and the pressure of that vapor (usually expressed in $\mathrm{mm} \mathrm{Hg}$ ) is called saturated vapor pressure [57]. This variable depends on air temperature and is obtained by (8).

$$
\Delta=\frac{4098\left[0.6108 \exp \left(\frac{17.27 * T_{\text {mean }}}{T_{\text {mean }}+237.3}\right)\right]}{\left(T_{\text {mean }}+237.3\right)^{2}}
$$

Where $\mathrm{T}_{\text {mean }}$ : average daily air temperature in ${ }^{\circ} \mathrm{C}$; exp: exponential function, 2.7183 (natural base logarithm).

\section{Evaporation (Ea)}

This value is obtained considering vapor pressure and wind velocity; all the data mentioned must be specific to the case study. It is calculated using (9).

$$
E a=0.35\left(0.50+0.54 v_{2}\right)\left(e_{s}-e\right)
$$

Where $\mathrm{v}_{2}$ : wind velocity at $2 \mathrm{~m}$ above the evaporating surface in $\mathrm{m} \mathrm{s}^{-1} ; \mathrm{e}_{\mathrm{s}}$ : saturation vapor pressure for the mean air temperature in $\mathrm{mm} \mathrm{hg}$; e: the vapor pressure of the air in $\mathrm{mm} \mathrm{Hg}$.

\section{Calculation of wind velocity}

Average daily wind velocity is expressed in $\mathrm{m} \mathrm{s}^{-1}$. The Penman's equation indicates that it should be measured $2 \mathrm{~m}$ above ground level. It is crucial to verify the height at which wind velocity is measured, as it is usually measured at different heights above the ground surface. However, the wind velocity measured at heights other than $2 \mathrm{~m}$ can be adjusted according to (10).

$$
u_{2}=u_{h} \frac{4.87}{\ln \ln (67.8 h-5.42)}
$$

Where $\mathrm{u}_{2}$ : wind velocity at $2 \mathrm{~m}$ above the ground surface in $\mathrm{m} \mathrm{s}^{-1} ; \mathrm{u}_{\mathrm{h}}$ : the wind velocity measured at a certain height above the ground surface 
in $\mathrm{m} \mathrm{s}^{-1}$; h: the height of the measurement above the ground surface in $\mathrm{m}$. For the present case study, the wind velocity was a datum provided by the weather station.

\section{Vapor pressure and saturation vapor pressure}

As saturation vapor pressure is related to air temperature, it can be calculated using (11).

$$
e_{(T)}=0.06108 \exp \left[\frac{17.27 T}{T+237.3}\right]
$$

Where $\mathrm{e}_{(\mathrm{T})}$ : saturation vapor pressure in $\mathrm{KPa}$; $\mathrm{T}$ : air temperature in ${ }^{\circ} \mathrm{C}$. Therefore, the mean saturation vapor pressure is calculated as the saturation vapor pressure between both minimum and maximum daily temperatures. Equations 12 and 13 show how temperatures take part in it:

$$
e_{(\operatorname{Tmax})}=0.06108 \exp \left[\frac{17.27 * T_{\max }}{T_{\max }+237.3}\right]
$$

and

$$
e_{(\operatorname{Tmin})}=0.06108 \exp \left[\frac{17.27 * T_{\min }}{T_{\min }+237.3}\right]
$$

Where $\mathrm{T}_{\max }$ : maximum daily temperature in ${ }^{\circ} \mathrm{C}$; $\mathrm{T}_{\min }$ : daily minimum temperature in ${ }^{\circ} \mathrm{C}$.

\section{Latent heat of vaporization (Hv) and net radiation ( $\left.\mathrm{Rn}^{\prime}\right)$}

Latent heat is the energy required by the quantity of a substance to change from solid to liquid (heat of fusion) or from liquid to gas (heat of vaporization). It should be noted that the heat is reversed for the phase change and not for the temperature increment.

As the net prime radiation $\left(R n^{\prime}\right)$ is expressed in $\mathrm{mm} \mathrm{day}^{-1}$, it must be divided between the latent heat of vaporization ( $\mathrm{Hv}$ ) and the density of the evaporated water $(\rho)$. Then, knowing that $\mathrm{Hv}=539.4 \mathrm{cal} \mathrm{gr}^{-1}$ and that $\rho=1 \mathrm{gr} \mathrm{cm}^{-3}$, we could find the value of $\mathrm{Rn}^{\prime}$ and calculate the mean daily evaporation for the present case study.

\section{Results}

This research considered the hydrological year from November 1, 2010, to October 31, 2011, a period during which a severe drought occurred in Mexico. In the dry season, the mean temperature was $14.5^{\circ} \mathrm{C}$, while the average maximum was $26.5^{\circ} \mathrm{C}$ and the average minimum was $2.5^{\circ} \mathrm{C}$. During April and May, there were temperatures of up to $37^{\circ} \mathrm{C}$. During December, January, and February, there were temperatures below $0^{\circ} \mathrm{C}$ and down to $-4.5^{\circ} \mathrm{C}$.

In the rainy season (June to October), there was a severe drought in the area. In this period, the average maximum temperature was $28.7^{\circ} \mathrm{C}$, the average minimum was $11.3^{\circ} \mathrm{C}$, and the average was $20^{\circ} \mathrm{C}$, that is, almost $38 \%$ higher than the temperature in the dry period. The month with the highest temperatures was June, exceeding $30^{\circ} \mathrm{C}$.

There are significant differences in temperatures between the low water period (dry season) and the drought season, observing that the radiation was more intense during the second. Temperature influences the magnitude of vapor and psychrometric pressures, values that fundamentally affect evaporation.

Fig. 2 presents a graph of the maximum daily temperatures and daily net radiation as a function of time for the hydrological year between November 2010 and October 2011 at the El Cazadero dam. Note a correlation between the data and that, during the drought period, these two variables increase in magnitude. The temperature increases from 5 to $7^{\circ} \mathrm{C}$, while the radiation from 0.5 to $1 \mathrm{~mm}$. For a season where frequent rainfall is expected, these figures can have a significant impact. 


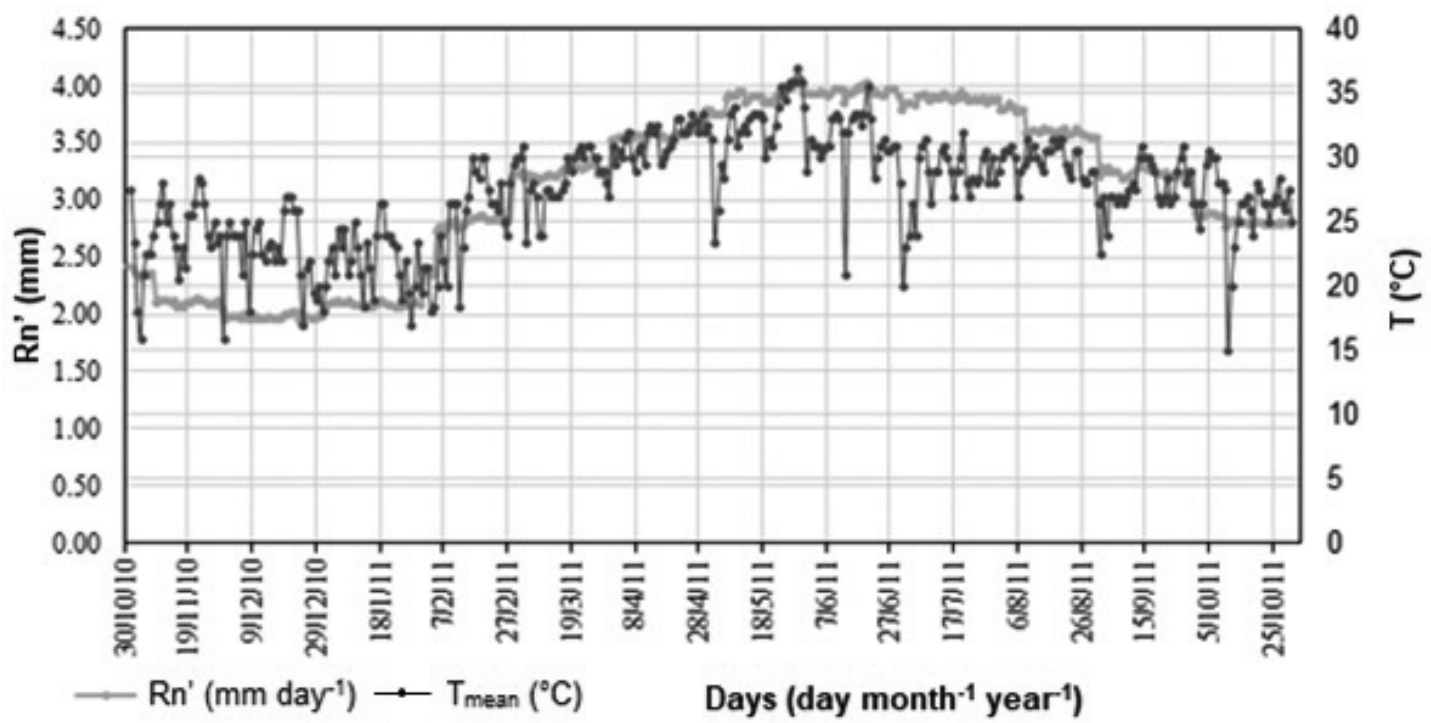

Fig. 2. Maximum daily temperatures and daily net radiation as a function of time. Hydrological year: Nov 2010-Oct 2011.

Source: Own elaboration

To understand this increment, consider that the amount of solar energy received in any region of the planet varies with the time of day, the season of the year, latitude, and particularly the atmospheric conditions. Some radiation is reflected by the Earth's surface or any other surface, known as "albedo." The albedo is variable in space and time, depending on the cloud cover, nature of the surface, the inclination of the solar rays, particles present in the air, among other factors. The variations in the magnitude of the radiation detected in this research directly affect the temperature changes.

It is known that the presence or absence of clouds is linked to the increase in temperatures and solar radiation that reaches the Earth. It is noteworthy that clouds reflect sunlight, absorb part of it together with gases such as ozone (reaching $50 \%$ of said incident radiation at the top of the atmosphere), regulate rainfall, and sift the amount of solar radiation to Earth. The period analyzed in this research is one in which there was a severe drought and absence of clouds, causing a notable increase in net radiation and, therefore, in temperature.

Net radiation is an essential meteorological factor in estimating evaporation. It is a numerator in the Penman's equation; therefore, the effect of its increase or decrease is directly reflected in the results. It is defined as the sum of short-wave radiation (captured by the free surface of the water) and longwave radiation (absorbed and emitted by the free surface of the water). This value, decisive in the calculations, increases substantially during droughts. Fig. 3 compares the results of the evaporation calculation by Penman's method and data obtained from El Cazadero or 32006 weather station. 


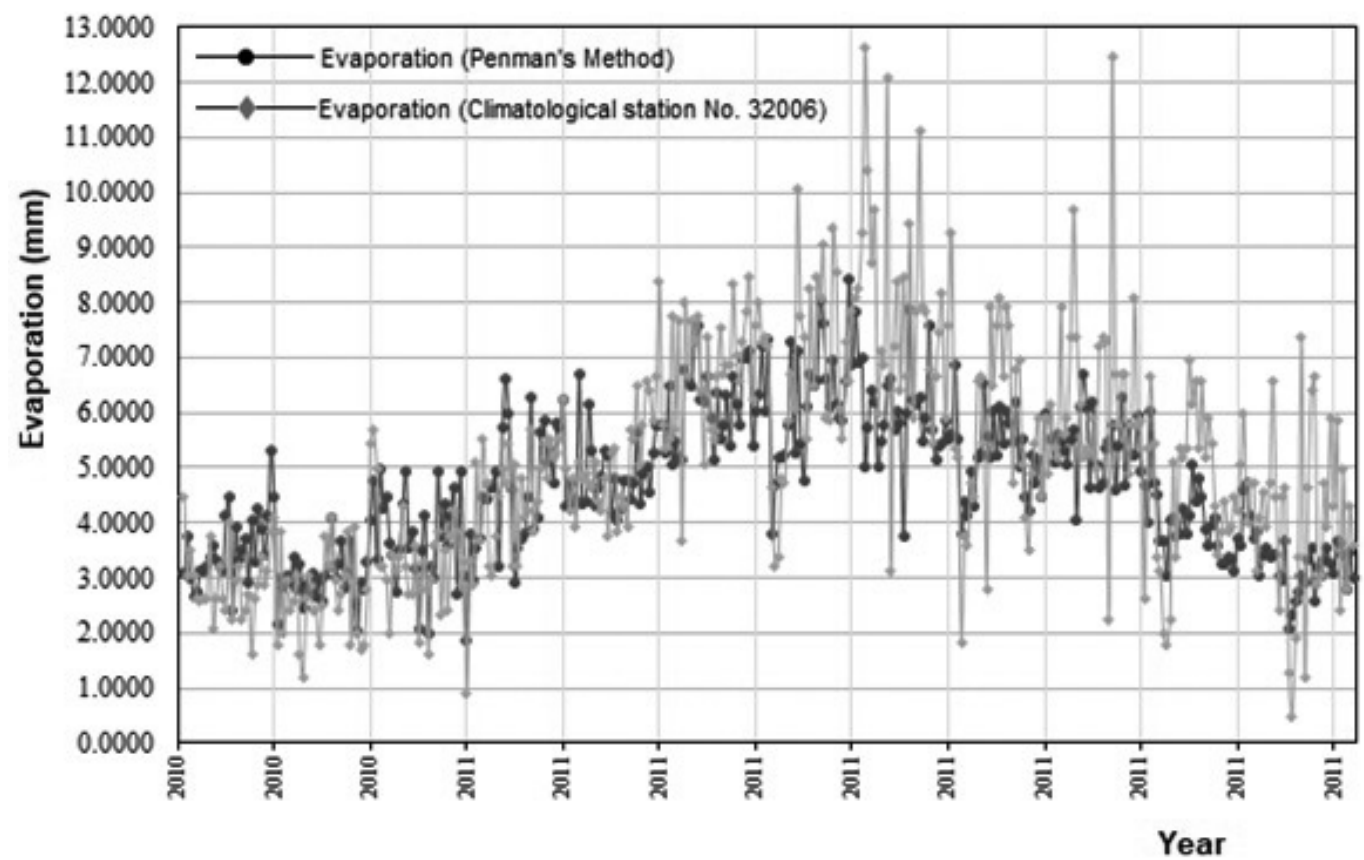

Fig. 3. Evaporation graphs using Penman's semi-empirical methodand data from El Cazadero or 32006 weather station.

Source: Own elaboration

As observed, the results obtained applying the proposed methodology follow a similar trend to those of the weather station, although for some specific cases, there are strong oscillations in the station values that may be caused by local factors. In Mexico, the dry and rainy seasons are well defined. This research considers that the dry season started in November 2010 and ended in May 2011, while the drought appeared in June 2011 and ended in October of the same year.

The separation of these seasons is clear. Theoretically, in the rainy season (June-October), evaporation should decrease because net radiation is affected by cloudiness. In this case, in the hydrological year concerned, an atypical drought occurred, increasing net radiation and, therefore, temperature.

Analyzing the dry season, the pattern shown by the results is similar to that of the data from the weather station, while the drought season has the most significant discrepancies.

In the drought season, there were values below those obtained by the weather station and differences in water sheet loss from 0.5 to $2.3 \mathrm{~mm}$ among the results obtained with the proposed method. It should be noted that the Penman's method is a semi-empirical equation, where the most critical or high impact variable is the 'net radiation.' The peaks shown in the graph are data from the weather station and are short-time extreme events where the difference in the sheet is up to $7 \mathrm{~mm}$.

Table 5 shows the results of the evaporation calculation for the first fifteen days of November 2010. $\mathrm{Rn}^{\prime}$ represents the premium net radiation in $\left(\mathrm{mm} \mathrm{day}^{-1}\right)$. Ea represents the evaporation as a function of wind velocity and vapor pressures, and $\Delta \gamma^{-1}$ is the relationship between the saturation vapor pressure for the mean temperature and the psychrometric constant, which is constant. For the present case, its value is $\gamma=390,779.989$ $\left(\mathrm{mm} \mathrm{hg}{ }^{\circ} \mathrm{C}^{-1}\right)$. The total evaporation of the studied period calculated with the Penman's equation turned out to be $1,711.49 \mathrm{~mm}$ year ${ }^{-1}$, while with the data from the weather station, it turns out to be $1,843.84 \mathrm{~mm}_{\text {year }}{ }^{-1}$. The difference between the two results is $\sim 100 \mathrm{~mm}^{-1}$ year $^{-1}$, approximately $7 \%$. 
Table 5. Daily evaporated water sheet for the hydrological year Nov 2010-Oct 2011

\begin{tabular}{|c|c|c|c|c|}
\hline Day & $\mathrm{Rn}^{\prime}$ (mm day-1) & EA & $\Delta y-1$ & Evaporation ( $m m$ day-1) \\
\hline 11/01/2010 & 2.38 & 4.31 & 1.69 & 3.0998 \\
\hline $11 / 02 / 2010$ & 2.36 & 5.90 & 1.55 & 3.7471 \\
\hline $11 / 03 / 2010$ & 2.31 & 3.80 & 1.23 & 2.9807 \\
\hline $11 / 04 / 2010$ & 2.28 & 3.04 & 0.98 & 2.6645 \\
\hline $11 / 05 / 2010$ & 2.30 & 3.27 & 1.13 & 2.7559 \\
\hline $11 / 06 / 2010$ & 2.31 & 4.14 & 1.25 & 3.1240 \\
\hline 11/07/2010 & 2.31 & 4.12 & 1.20 & 3.1306 \\
\hline $11 / 08 / 2010$ & 2.32 & 4.31 & 1.29 & 3.1917 \\
\hline $11 / 09 / 2010$ & 2.06 & 5.29 & 1.40 & 3.3989 \\
\hline $11 / 10 / 2010$ & 2.08 & 5.85 & 1.51 & 3.5829 \\
\hline $11 / 11 / 2010$ & 2.09 & 5.39 & 1.62 & 3.3479 \\
\hline $11 / 12 / 2010$ & 2.07 & 4.93 & 1.53 & 3.2040 \\
\hline $11 / 13 / 2010$ & 2.07 & 4.78 & 1.53 & 3.1433 \\
\hline $11 / 44 / 2010$ & 2.06 & 7.18 & 1.45 & 4.1553 \\
\hline $11 / 15 / 2010$ & 2.07 & 8.16 & 1.53 & 4.4784 \\
\hline $11 / 16 / 2010$ & 2.02 & 2.84 & 1.20 & 2.3968 \\
\hline $11 / 17 / 2010$ & 2.04 & 6.35 & 1.31 & 3.9078 \\
\hline $11 / 18 / 2010$ & 2.03 & 4.92 & 1.23 & 3.3243 \\
\hline $11 / 19 / 2010$ & 2.06 & 5.57 & 1.45 & 3.4955 \\
\hline
\end{tabular}

Source: Own elaboration

Note that due to the uneven heating of the seas and continental surfaces, changes in temperature and pressure occur in the air, which in turn produces the set of wind systems and air currents, known as the general circulation of the atmosphere. This phenomenon is closely linked to the main precipitation areas, defining the large climate regions of the world.

The solar activity contributes to modifying atmospheric movements, and with it, the occurrence of droughts. A clear relationship has been observed between the variable number of sunspots and the intensity of the incident solar radiation flux on Earth. The presence of sunspots, which occurs every eleven years approximately, modifies the rate with which solar energy reaches the Earth and influences the change in temperature and atmospheric pressure, thus altering the regular patterns of circulation [58].

In the period analyzed in this research, there was greater intensity of solar radiation since it coincided with the beginning of the Solar Cycle 24. There was an unusual solar activity, which consisted of numerous solar explosions better known as sunspots. During 2011 and 2012, solar activity was on the rise, with a maximum in 2012, as shown in Fig. 4, which could explain the increase in sunny days. 
Jan. $1,1966 \longrightarrow$ Jan. 1, 2021

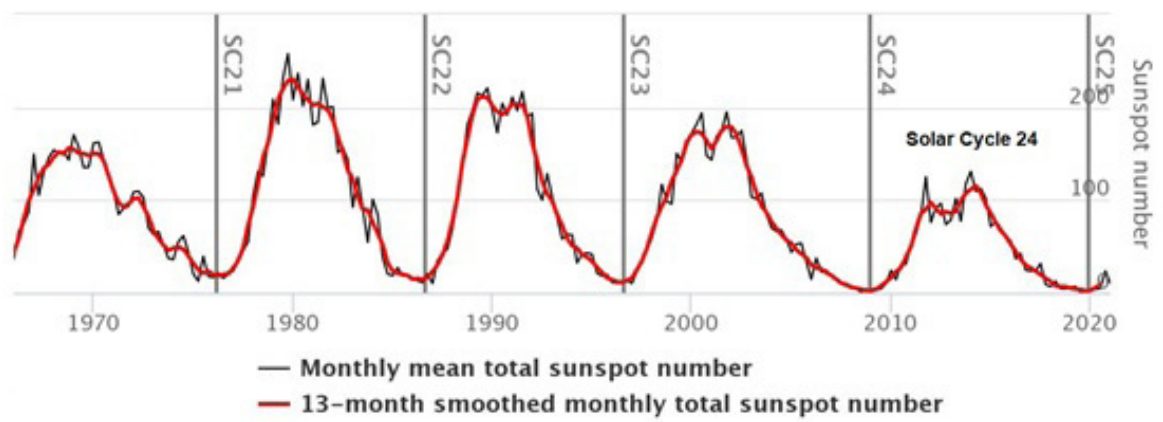

Fig. 4. International number of sunspots.

Source: Taken from https://www.spaceweatherlive.com/en/solar-activity/solar-cycle/historical-solar-cycles.html

The relevance of solar activity in the climate has been demonstrated in different studies. In the case of Mexico, research was carried out in the Yucatan peninsula to reconstruct the climatic history of the region in the last 2,600 years, finding a recurring pattern of drought with a periodicity of 208 years. It is directly related to the documented variations in solar activity in periods of 206 years, concluding that an essential component of droughts in this geographical area is the variation in solar activity [59].

The OHWL and EHwL areas of the El Cazadero dam were considered constant to estimate the total volume of evaporated water. The area covered by the dam's oHwL is 457.53 ha, while the EHWL, according to Conagua's data, reaches an area of 682.44 ha. Therefore, the evaporated water in volume, considering the oHwL surface, is $7,834,016.42 \mathrm{~m}^{3}\left(\sim 7.83 \mathrm{Hm}^{3}\right)$, while for the EHWL surface, the value is $11,679,912.10 \mathrm{~m}^{3}\left(\sim 11.7 \mathrm{Hm}^{3}\right)$ of evaporated water.

Economically, the volumes of evaporated water constitute a significant loss, which could serve to guarantee a temporary supply in different sectors (urban, industrial, or agricultural), just when droughts occur [33], [60], [61]. The Potable Water Rates Information System (sITAP, for its acronym in Spanish), designed by the Mexican Institute of Water Technology, contains the rates for drinking, sewerage, and sanitation water in the domestic, commercial, and industrial sectors for 56 cities in Mexico from 2006 to 2018. In Zacatecas, during 2010 and 2011, the drinking water rate for the industrial sector was 0.75 dollars $\mathrm{m}^{-3}$ (see Fig. 5).

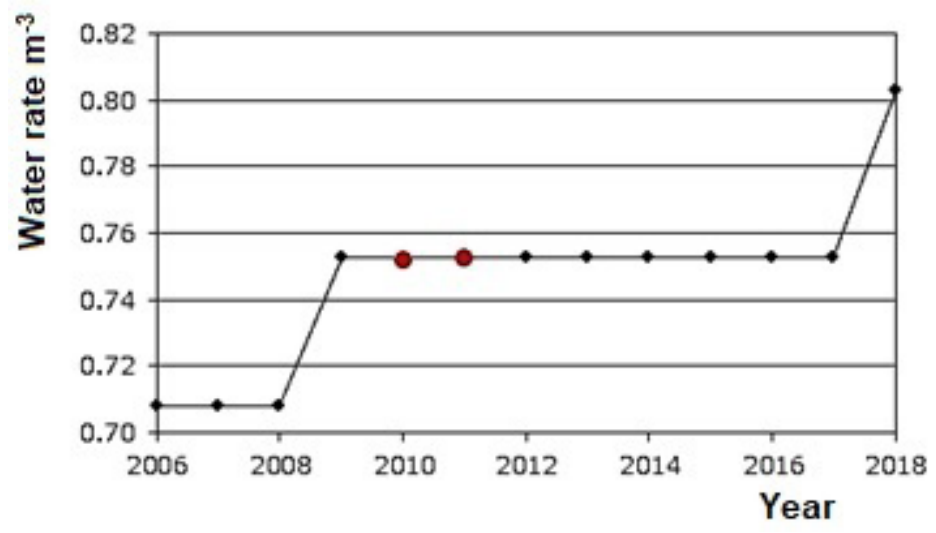

Fig. 5. Historical graph of the price and rate of drinking water for the industrial sector in Zacatecas. Source: Taken from [62]. 
To have economic figures and understand the context, if we considered the volume of evaporated water calculated with oHWL and its economic cost for the sector per $\mathrm{m}^{3}$, this would be USD $5,896,922.30$ ( $\sim$ USD 5.9 million), and in the case of EHWL, it would be USD 8,791,854.71 ( USD 8.8 million). In 2014, the budget for expenditures of the Zacatecas Inter-municipal Board of Potable Water and Sewerage was USD 12,409,485.97 [63]; in other words, in the proposed scenario, what could be collected from the water service to the industrial sector represents 47.5 and $70.8 \%$ of this amount, respectively. This example intends to illustrate that in economic terms, the volumes of evaporated water can reach significant figures. For all cases, 2019 us dollars were used [64].

Lowe et al. (2009) mention that an aspect to consider in estimating evaporation in reservoirs is the uncertainty associated with the measurements [65]. Although it is estimated that the uncertainty in the calculations could be up to $40 \%$, if this percentage were applied to the results obtained in the hypothetical example presented, the resulting figures would still be important. This point is crucial to guarantee the water supply in new projects since their economic viability will depend on the volume of water that can be recovered. The uncertainty associated with the volumes of water that could evaporate constitutes a risk factor for the investment. In some cases, the magnitude of the uncertainty may be unacceptably high, and decision-makers may consider investments at the beginning of the project that support its reduction, which is also related to the necessity for more precise data that could be obtained from better technologies [33], [66], [67].

\section{Conclusions}

Evaporation has been investigated in the past. Currently there is a renewed interest in reviewing calculation methods and techniques to mitigate it, having as a primary motivation the increasing demand for water due to population growth, economic activities, and its decreased availability. This research verified that the volume of water in the form of vapor returned to the atmosphere because of the sun's radiation on the free surface of the water can represent a percentage that substantially impacts the volume of water stored in reservoirs or dams.

Measuring evaporation is a complex process; measurements are often approximate, and adjustment methods must be tuned up to determine a value. This research confirmed the importance of having reliable data to reach results closer to reality, being necessary to review and update existing technologies in Mexico for climatological data acquisition.

Even though evaporation in reservoirs is not a new issue and that countries such as Spain, India, Australia, United States, and others have made scientific advances, Mexico, where situations of aridity and low water availability exist, has not carried out studies or provided relevant evidence that contribute to finding new alternatives to mitigate evaporation in reservoirs. In arid areas with frequent droughts or low rainfall problems, it is essential to implement techniques that allow water to be retained for as long as possible, preventing adverse effects on the economic and social development of communities. This research established that the water in the region is used for agriculture, livestock, fishing, and recreational purposes.

In Mexico, the loss of water by evaporation has not been raised as a significant problem. Science and technology policies have not been proposed to find and implement new alternatives to mitigate this phenomenon, which is reflected in the existing dams not having any technique or method (floating and suspended covers) to retain water vapor. Projects of this type have great potential and would benefit communities.

Evaporation is the main route of water loss in lakes, wetlands, and others; it controls the hydrological dynamics of the systems and conditions planning and management to an equal or greater extent than rainfall. Despite this manifest importance, estimates of evaporation in water storage and control systems, such as reservoirs, are far from realistic. In other words, water is being managed in most cases with a very high degree of uncertainty, motivated by a lack of application of methods to measure evaporation [49]. 
By applying Penman's method for the calculation of evaporation in the El Cazadero dam for the hydrological year 2010-2011, during which Zacatecas suffered a severe drought, we obtained an evaporation rate of $1,711.49 \mathrm{~mm}^{\text {year-1 }}{ }^{-1}$ of water, representing a volume of $7.8 \mathrm{Hm}^{3}$ year ${ }^{-1}$ for the OHWL surface and $11.7 \mathrm{Hm}^{3}$ year-1 for the EHWL. Considering the cost of water for different sectors, the economic losses due to evaporation are significant; in some cases, figures could represent a high percentage of the budget of water and sanitation companies and even exceed average consumption.

It is essential to continue carrying out this type of research since evaporimeters or standard devices to measure water evaporation (the evaporation trays, for example) do no produce actual results. However, they are still used today as no other measurements are required. The development of new methodologies to estimate evaporation in reservoirs is vital to have more reliable estimates and forecasts that optimize water resource management. The new proposals must consider the calculation of the uncertainty of results. The measurement of evaporation, its spatial distribution, and the implementation of measures to mitigate it would increase water availability in the regions of the country most vulnerable to droughts, thus ensuring the supply of water to strategic sectors.

Evaporation can be reduced artificially using some engineering techniques such as: a) applying organic monolayers [68]-[69]; b) moving cooler water to the surface; c) covering the water surface or creating a shadow over it [70]. Various studies have proven that it is possible to reduce evaporation rates between 50 and $90 \%$ by providing shade, while monolayers can reduce them between 5 and $30 \%$. The performance of these methods depends on atmospheric conditions, for example, the increase in wind velocity, temperature, and solar radiation [71]. Another option for conserving reservoir water is redirecting it to underground aquifers, a technique known as managed aquifer recharge [71]-[72].

Mexico should implement large vessels or dams with state-of-the-art technology, specialized meteorological measurement equipment or stations, remote sensors, and others, and keep records to obtain reliable data for several years, necessary for the application of other calculation methods. These strategies will allow developing more precise mathematical or physical models for calculating evaporation.

Considering the effects of climate change or climate variability, which could enhance the evaporation of water in reservoirs, it is necessary to carry out more research using both field information and numerical models to make estimations of evaporation rates in the short and long term possible, both in existing dams and in areas where the construction of new reservoirs is planned.

\section{References}

[1] D. F. Campos Aranda, Procesos del ciclo hidrológico, San Luis Potosí, México: Universidad Autónoma de San Luis Potosí, 1998.

[2] P. Guido, Cambio climático: bases para la adaptación y mitigación en las regiones hidrológico-administrativas en México, México, 2019. [Online] ISBN: 978-6078629-14-5.

[3] K. Verbist, F. Santibañez, D. Gabriels, and G. Soto, Atlas de Zonas Áridas de América Latina y El Caribe. Chile: Cazalac. 2010.

[4] F. F. O. García and L. G. Matías, Sequías. México: Centro Nacional para la Prevención de Desastres (Cenapred), 2002.

[5] D. A. Wilhite. Drought: A Global Assessment, vol. I, London: Routledge, 2000.

[6] P. Rakhecha and P. Vijay Singh, Applied hydrometeorology, New Delhi, India: Springer Science \& Business Media, 2009.

[7] S. C. Herring, N. Christidis, A. Hoell, J. P. Kossin, C. J. Schreck III, and P. A. Stott, "Explaining extreme events of 2016 from a climate perspective," Bull. Amer. Meteor. Soc., vol. 99, no. 1, pp. S1-S157, 2018. https:// doi.org/10.1175/bams-explainingextremeevents2016.1

[8] D. Guha-Sapir, R. Below, and P. Hoyois, EM-DAT, The Emergency Events Database-The OFDA/CRED International Disaster Database. Brussels, Belgium: Université catholique de Louvain (UCL)-CRED, 2016.

[9] R. A. Giner, L. C. Fierro, and L. F. Fernando Negrete, Análisis de la problemática de la sequía 2011-2012 y sus efectos en la ganadería y agricultura de temporal, Mexico: Comisión Nacional de las Zonas Áridas (Conaza), 2011. uRI: http://10.0.0.98/xmlui/handle/1/1626 
[10] J. L. Caballero, "México, en el umbral de una sequía histórica," Economista, vol. 23, 2012.

[11] A. S. Goudie, Human impact on the natural environment. Hoboken, NJ: John Wiley \& Sons, 2018.

[12] J. F. Maestre-Valero, D. Martínez-Granados, V. Martínez-Alvarez, and J. Calatrava, "Socio-economic impact of evaporation losses from reservoirs under past, current and future water availability scenarios in the semi-arid Segura Basin," Water Resour. Manag., vol. 27, no. 5, pp. 1411-1426, 2013. https://doi.org/10.1007/ s11269-012-0245-4

[13] D. Martínez-Granados, J. F. Maestre-Valero, J. Calatrava, and V. Martínez-Álvarez, "The economic impact of water evaporation losses from water reservoirs in the Segura basin, SE Spain," Water Resour. Manag., vol. 25, no. 13, pp. 3153-3175, 2011. https://doi.org/10.1007/ s11269-011-9850-X

[14] F. Molle and A. Closas, "Co-management of groundwater: A review," Wiley Interdiscip. Rev. Water, vol. 7, no. 1, p. e1394, 2020.

[15] H. Afkhami, H. Malekinezhad, and E. Esmailzadeh, "Effect of floating balls on evaporation reduction from open water resources (Case study: Tailing dam of Sarcheshmeh copper mine) Kerman," Arid Biome, vol. 8, no. 1, pp. 59-73, 2018. https://doi.org/10.29252/aridbiom.8.1.59

[16] E. Elba, B. Urban, B. Ettmer, and D. Farghaly, "Mitigating the Impact of Climate Change by Reducing Evaporation Losses: Sediment Removal from the High Aswan Dam Reservoir," Am. J. Clim. Change, vol. 6, no. 02, pp. 230-246, 2017. https://doi.org/10.4236/ ajcc.2017.62012

[17] A. Khandelwal, A. Karpatne, M. E. Marlier, J. Kim, D. P. Lettenmaier, and V. Kumar, "An approach for global monitoring of surface water extent variations in reservoirs using Modis data," Remote Sens. Environ., vol. 202, pp. 113-128, 2017. https://doi.org/10.1016/j. rse.2017.05.039

[18] F. Helfer, C. Lemckert, and H. Zhang, "Investigating techniques to reduce evaporation from small reservoirs in Australia," in Proc. 34th World Congr. Int. Assoc. Hydro-Environment Research and Engineering: - 33rd Hydrology and Water Resources Symp. and 10th Conf. on Hydraulics in Water Engineering, Brisbane, Australia, 2011, p. 1747.

[19] S. A. Hashemi Monfared, M. Rezapour, and T. Zhian, "Using Windbreaks for Decreasing Lake and Reservoir Evaporation: A Case Study from Iran.” Pol. J. Environ. Stud., vol. 28, no. 4, pp. 2289-2298, 2019. https:// doi.org/10.15244/pjoes/89984
[20] P. Rosa-Clot, "FPV and Environmental Compatibility," in Floating PV Plants, Academic Press, 2020, pp. 101-118. https://doi.org/10.1016/b978-0-12-8170618.00009-9

[21] K. Simon, R. Shanbhag, and A. H. Slocum, "Reducing evaporative water losses from irrigation ponds through the reuse of polyethylene terephthalate bottles," J. Irrig. Drain. Eng., vol. 142, no. 2, p. 06015005, 2015. https://doi.org/10.1061/(asce)ir.1943-4774.0000972

[22] M. E. Taboada, L. Cáceres, T. A. Graber, H. R. Galleguillos, L. F. Cabeza, and R. Rojas, "Solar water heating system and photovoltaic floating cover to reduce evaporation: Experimental results and modeling," Renew. Energy, vol. 105, pp. 601-615, 2017. https:/doi. org/10.1016/j.renene.2016.12.094

[23] A. H. Cavusoglu, X. Chen, P. Gentine, and O. Sahin, "Potential for natural evaporation as a reliable renewable energy resource," Nat. Commun., vol. 8, no. 1, p. 617, 2017. https://doi.org/10.1038/s41467-017-00581-w

[24] P. C. Milly and K. A. Dunne, "Potential evapotranspiration and continental drying," Nat. Clim. Change, vol. 6, no. 10, pp. 946-949, 2016. https://doi.org/10.1038/ nclimate 3046

[25] A. Azhoni, S. Jude, and I. Holman, "Adapting to climate change by water management organizations: Enablers and barriers," J. Hydrol., vol. 559, pp. 736-748, 2018. https://doi.org/10.1016/j.jhydrol.2018.02.047

[26] S. Z. Losgedaragh and M. Rahimzadegan, "Evaluation of SEBS, SEBAL, and METRIC models in estimation of the evaporation from the freshwater lakes (Case study: Amirkabir dam, Iran)," J. Hydrol., vol. 561, pp. 523531, 2018. https://doi.org/10.1016/j.jhydrol.2018.04.025

[27] W. J. Shuttleworth, Evaporation, uk: Institute of Hydrology, the Natural Environment Research Council, 1979.

[28] J. Collado, "Hidrología superficial en México: estado del arte y necesidades de investigación," Tecnol. Cienc. Agua, pp. 62-81, 2015.

[29] B. Ait Hssaine, O. Merlin, J. Ezzahar, N. Ojha, S. Er-Raki, and S. Khabba, "An evapotranspiration model self-calibrated from remotely sensed surface soil moisture, land surface temperature and vegetation cover fraction: application to disaggregated smos and MODIs data," Hydrol. Earth Syst. Sci., vol. 24, no. 4, pp. 1781-1803, 2020. https://doi.org/10.5194/hess-24-17812020

[30] D. A. I. Lindong, "A Case Analysis on Inverse Phenomenon of Evaporation Paradox," J. Arid Meteor., vol. 35, no. 6, pp. 998-1003, 2017. 
[31] Z. Şen, "Water structures and climate change impact: A review," Water Resour. Manag., vol. 34, no. 13, pp. 4197-4216, 2020. https://doi.org/10.1007/s11269-02002665-7

[32] S. Araghinejad, S. M. Hosseini-Moghari, and S. Eslamian, "Reservoir Operation during Drought," in Handbook of Drought and Water Scarcity, CRC Press, 2017, pp. 283-292.

[33] K. Friedrich et al., "Reservoir evaporation in the Western United States: current science, challenges, and future needs," Bull. Amer. Meteorol. Soc., vol. 99, no. 1, pp. 167-187, 2018. https://doi.org/10.1175/ bams-d-15-00224.1

[34] G. J. Byrne, J. R. Benbrook, E. A. Bering, D. Oró, C. O. Seubert, and W. R. Sheldon, "Observations of the stratospheric conductivity and its variation at three latitudes," J. Geophys. Res. Atmos., vol. 93, no. D4, pp. 3879-3891, 1988. https://doi.org/10.1029/jd093id04p03879

[35] L. Wang, S. Han, and F. Tian, "Comparison of formulating apparent potential evaporation with pan measurements and Penman methods," J. Hydrol., vol. 592, p. 125816, 2021. https://doi.org/10.1016/j.jhydrol.2020.125816

[36] H. L. Penman, "Natural evaporation from open water, bare soil and grass," Proc. Math. Phys. Sci., vol. 193, no. 1032, pp. 120-145, 1948. https://doi.org/10.2135/cropsci2019.05.0292

[37] H. L. Penman, "Estimating evaporation," Eos Trans. $A G U$, vol. 37, no. 1, pp. 43-50, 1956.

[38] M. R. Acuña Bardales, “Calibración de las fórmulas empíricas de evapotranspiración de referencia, respecto a la evaporación del tanque tipo a, en la estación de Purhuay-Huari,” B.S. thesis, Univ. Nac. Santiago Antúnez de Mayolo, Perú, 2020.

[39] G. H. Calvo, "Estimación de la evapotranspiración a escala regional mediante teledetección satelital," Ph.D. dissertation, Univ. Nac. La Plata (UNLP), Argentina, 2019.

[40] I. W. Sutapa and S. Wicana, "Sensitivity of methods for estimating potential evapotranspiration to climate change," IOP Conf. Series Earth Environ. Sci., vol. 437, no. 1, p. 012039, 2020. https://doi.org/10.1088/1755$1315 / 437 / 1 / 012039$

[41] R. G. Allen, L. S. Pereira, D. Raes, and M. Smith, "Evapotranspiración del cultivo. Guías para la determinación de los requerimientos de agua de los cultivos," FAO, Roma, Estudio FAO, Riego y Drenaje no. 56, 1988.

[42] T. A. McMahon, B. L. Finlayson, and M. C. Peel, "Historical developments of models for estimating eva- poration using standard meteorological data," Wiley Interdiscip. Rev. Water, vol. 3, no. 6, pp. 788-818, 2016. https://doi.org/10.1002/wat2.1172

[43] H. Farzanpour, J. Shiri, A. A. Sadraddini and S. Trajkovic, "Global comparison of 20 reference evapotranspiration equations in a semi-arid region of Iran," Hydrol. Res., vol. 50, no. 1, pp. 282-300, 2019. https:// doi.org/10.2166/nh.2018.174

[44] N. Sriwongsitanon, T. Suwawong, S. Thianpopirug, J. Williams, L. Jia, and W. Bastiaanssen, "Validation of seven global remotely sensed ET products across Thailand using water balance measurements and land use classifications," J. Hydrol. Reg. Stud., vol. 30, p. 100709 , 2020. https://doi.org/10.1016/j.ejrh.2020.100709

[45] M. Majidi, A. Alizadeh, A. Farid, and M. Vazifedoust, "Estimating evaporation from lakes and reservoirs under limited data condition in a semi-arid region," Water Resour. Manag., vol. 29, no. 10, pp. 3711-3733, 2015. https://doi.org/10.1007/s11269-015-1025-8

[46] L. Wang, O. Kisi, B. Hu, M. Bilal, M. Zounemat-Kermani, and H. Li, "Evaporation modelling using different machine learning techniques," Int. J. Climatol., vol. 37, no. 1076-1092, 2017. https://doi.org/10.1002/ joc. 5064

[47] O. Kisi and S. Heddam, "Evaporation modelling by heuristic regression approaches using only temperature data," Hydrol. Sci. J., vol. 64, no. 6, pp. 653-672, 2019. https://doi.org/10.1080/02626667.2019.1599487

[48] R. J. Nathan and T. A. McMahon, "Recommended practice for hydrologic investigations and reporting," Australas. J. Water Resour., vol. 21, no. 1, pp. 3-19, 2017. https://doi.org/10.1080/13241583.2017.1362136

[49] T. C. Winter, "Uncertainties in estimating the water balance of lakes," J. Am. Water Resour. Assoc., vol. 17, no. 1, pp. 82-115, 1981. https://doi.org/10.1111/j.1752-1688.1981.tb02593.x

[50] J. M. Molina, V. Martínez, A. Baille, and M. M. G. Real, "Estimación de la evaporación en embalses de riego mediante un modelo de balance de energía," Ing. Agua, vol. 13, no. 3, pp. 219-230, 2006. https:/doi. org/10.4995/ia.2006.2892

[51] Y. W. Youssef and A. Khodzinskaya, "A review of evaporation reduction methods from water surfaces," E3S Web Conf., vol. 97, p. 05044, 2019. https://doi. org/10.1051/e3sconf/20199705044

[52] J. L. Monteith, "Evaporation and Environment," in, 19th Symp. Soc. Exptl. Biol., Cambridge, 1965, pp. 205-234.

[53] J. T. Moreno Sánchez, "Levantamiento Aerofotogramétrico y Topobatimétrico de la Presa Cazadero, 
Municipio Sain Alto Zacatecas," B.S. thesis, Fac. Ing., Div. Ing. Civil y Geomática, Univ. Nac. Auton. Mexico, Mexico, 2014.

[54] S. Henderson and M. F. Wilson, "Surface albedo data for climatic modeling," Rev. Geophys., vol. 21, no. 8, pp. 1743-1778, 1983. https://doi.org/10.1029/ rg021i008p01743

[55] E. Jáuregui, "Una primera estimación de la distribución de la radiación global y neta en México," Recur. Hidraul., vol. VII, no. 2, pp. 96-105, 1978.

[56] V. Estrada-Cajigal Ramírez and R. Almanza Salgado, Irradiaciones global, directa y difusa, en superficies horizontales e inclinadas, así como irradiación directa normal, en la República Mexicana, Cuernava, Mexico: Solartronics, 2005. Available: http://www.solartronic. com/download/radiacion.pdf

[57] L. Zotarelli, M. D. Dukes, C. C. Romero, K. W. Migliaccio and K. T. Morgan, Step by step calculation of the Penman-Monteith Evapotranspiration (FAO-56 Method), Gainesville, FL: University of Florida, 2010.

[58] J. Lean and D. Rind, "Earth's Response to a Variable Sun," Science, vol. 292, no. 5515, pp. 234-236, 2011. https://doi.org/10.1126/science.1060082

[59] D. A. Hodell, M. Brenner, J. H. Curtis, and T. Guilderson, "Solar Forcing of Drought Frequency in the Maya Lowlands," Science, vol. 292, no. 5520. pp. 1367-1370, 2011. https://doi.org/10.1126/science.1057759

[60] E. Vallino, L. Ridolfi, and F. Laio, "Measuring economic water scarcity in agriculture: a cross-country empirical investigation," Environ. Sci. Policy, vol. 114, pp. 73-85, 2020. https://doi.org/10.1016/j.envsci.2020.07.017

[61] P. Greve et al., "Global assessment of water challenges under uncertainty in water scarcity projections," Nat. Sustain., vol. 1, no. 9, pp. 486-494, 2018. https://doi. org/10.1038/s41893-018-0134-9

[62] SITAP Potable Water Rates Information System (2019). Available: http://187.189.183.90/

[63] Junta Intermunicipal de Agua Potable y Alcantarillado de Zacatecas, Acta de reunión ordinaria del H. Consejo Directivo, Zacatecas, 2013. Available: http://jiapaz. gob.mx/InformacionFinanciera/Archivos/2014/Presupuesto2014.pdf
[64] Banco de México. Available: https://www.banxico. org. $\mathrm{mx} /$

[65] K. Ren, S. Huang, Q. Huang, H. Wang, G. Leng, and $\mathrm{Y}$. $\mathrm{Wu}$, "Defining the robust operating rule for multi-purpose water reservoirs under deep uncertainties," J. Hydrol., vol. 578, p. 124134, 2019. https://doi. org/10.1016/j.jhydrol.2019.124134

[66] J. Sun and C. Guan, "Inversion of Evaporation and Water Vapor Transport Using HY-2 Multi-Sensor Data," J. Ocean Univ. China, vol. 19, no. 1, pp. 13-22, 2020. https://doi.org/10.1007/s11802-020-4197-7

[67] G. Zhao and H. Gao, "Estimating reservoir evaporation losses for the United States: Fusing remote sensing and modeling approaches," Remote Sens. Environ., vol. 226, pp. 109-124, 2019. https://doi.org/10.1016/j. rse.2019.03.015

[68] D. McJannet, F. Cook, J. Knight, and S. Burn, "Evaporation reduction by monolayers: overview, modelling, and effectiveness," Urban Water Security Research Alliance, Tech. Rep. no. 6, 2008.

[69] B. Gallego-Elvira, V. Martínez-Alvarez, P. Pittaway, G. Brink, G., and B. Martín-Gorriz, "Impact of micrometeorological conditions on the efficiency of artificial monolayers in reducing evaporation," Water Resour. Manag., vol. 27, no. 7, pp. 2251-2266, 2013. https://doi. org/10.1007/s11269-013-0286-3

[70] Y. W. Youssef and A. Khodzinskaya, "A review of evaporation reduction methods from water surfaces," E3S Web Conf., vol. 97, p. 05044, 2019. https://doi. org/10.1051/e3sconf/20199705044

[71] P. Dillon and M. Arshad, "Managed aquifer recharge in integrated water resource management," in: Integrated Groundwater Management Cham: Springer, 2016, pp. 435-452. https://doi.org/10.1007/978-3-319-23576$9 \_17$

[72] S. Prathapar, S. Dhar, G. T. Rao, and B. Maheshwari, "Performance and impacts of managed aquifer recharge interventions for agricultural water security: A framework for evaluation," Agric. Water Manag., vol. 159, pp. 165-175, 2015. https://doi.org/10.1016/j. agwat.2015.06.009 
